NASA Technical Memorandum 105191

AIAA-91-3550

33692

\title{
Slush Hydrogen Propellant Production, Transfer, and Expulsion Studies at the NASA K-Site Facility
}

Terry L. Hardy and Margaret V. Whalen

Lewis Research Center

Cleveland, Ohio

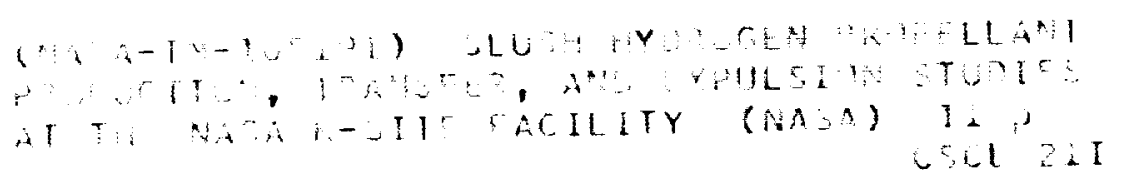

$\checkmark 1-\because \cdots+\cdots$

Unc 1.5

$\theta \mathbf{B} / 2$ an $30^{2}=$

Prepared for the

Conference on Advanced Space Exploration Initiative Technologies cosponsored by the AIAA, NASA, and OAI

Cleveland, Ohio, September 4-6, 1991

\section{N/Sก}


capacity of slush hydrogen may provide increased storage time of hydrogen in these depots, thus increasing their effectiveness. Finally, slush hydrogen may provide benefits for advanced launch systems that may be required for SEl. Slush hydrogen could be used to increase the payload to orbit of the launch vehicle, as the higher density of slush hydrogen implies that more hydrogen could be placed in the fuel tanks, or the size of the velicle could be reduced, as with the NASP.

Although several small-scale studies were conducted at the National Institute of Standards and Technology (NIST, formerly the National Bureau of Standards) in the 1960's and 1970 's, ${ }^{\text {f-k }}$ little data existed prior to the NASP program on large-scale production and transfer of slush hydrogen. in addition, previous studies at the NASA Lewis Research Center $\mathrm{K}$-Site Facility exanined the pressurized expulsion of liquid hydrogen, ${ }^{0-11}$ but little data was available on the pressure control of slush hydrogen tanks during the pressurization and pressurized expulsion processes. Therefore, a program was started at NASA Lewis (LeRC) to expand the slush hydrogen experimental database in the areas of production, transfer, and pressurized expulsion.

The slush hydrogen experiments were conducted at the NASA Lewis K-Site Facility located at Plum Brook Station in Sandusky, Ohio. The K-Site Facility was designed and used in the 1960's and 1970's to conduct testing on cryogenic propellant tankage. The facility was modified to support siush hydrogen production and handling tests for the NASP program. In the experiments described here, slush hydrogen was produced in a slush hydrogen generator and transferred to a $5 \mathrm{ft}$ diameter spherical test tank for use in the pressurized expulsion tests. The pressurized expulsion tests were conducted using gaseous hydrogen pressurant. This report provides a summary description of the experiments performed during the first test series, conducted from September to October, 1990. Sample results from the production, transfer, pressurization, and pressurized expulsion tests, published in NASP technical memoranda, ${ }^{12-15}$ are provided.

\section{K-Site Facility Description}

\section{Facility}

NASA-LeRC's Plum Brook K-Site facility was designed to allow experimental evaluation of flow dynamics and thermal protection subsystems for cryogenic propellant tankage. The facility, shown in Fig. 1, includes the test building which houses the vacuum chamber, the remotely located control room, cryogenic and gas storage areas, and the new slush hydrogen production subsystem. All the tests were conducted under vacuum in the facility's $25 \mathrm{ft}$ diameter spherical vacuum chamber (Fig. 2) to reduce the heat transfer to the propellant test tank. The vacuum level in the chamber during this testing was approximately $1 \times 10^{-5}$ torr.
A heat exchanger was used to precondition pressurant gas by heating it with steam. This test series used ambient $(520 \mathrm{R})$ and warm $\left(620^{\circ} R\right)$ pressurant gas. The flow rate of the pressurant gas was measured using an orifice meter. A closedloop pressure control circuit was used to control the initial rate of pressurization of the test tank and to maintain constant tank pressure during the expulsion.

The slush hydrogen generator was installed during facility modifications to provide a slush hydrogen production and handling capability for NASP testing. The generator, shown in Fig. 3, is a 1300 gallon capacity dewar with a liquid nitrogen shield in addition to the vacuum jacket with multilayer insulation. In addition to the generator, a $6000 \mathrm{ft}^{3} / \mathrm{min}$ (cfin) vacuum pumping subsystem was installed for use in the evaporative cooling (freeze-thaw) production of the slush hydrogen.

The generator has two viewports, a mixer, and instrumentation to monitor temperature, pressure, liquid level, and density during the production of a batch of slush hydrogen. The density of the slush hydrogen in the generator was measured using a nuclear radiation attenuation (NRA) densimeter with a 150 millicurie $(\mathrm{mCi})$ cesium 137 source.

The slush hydrogen was transferred from the slush hydrogen generator to the test tank through a 1.5 in. Schedule 5 stainless steel vacuum-jacketed transfer line. The transfer line was $\sim 125 \mathrm{ft}$ long and included 5 valves and various elbows, mitre bends, bayonet fittings, bellows and flex lines. A full description of this transfer system is provided in Ref. 15. The transfer line was equipped with a pressure tap located at the outlet of the slush generator to provide an upstream pressure measurement.

\section{Test Package}

The test tank used in this testing was a $5 \mathrm{ft}$ diameter spherical tank constructed of 6061 aluminum with $0.31 \mathrm{in}$. thick walls. The total volume of the test tank was $\sim 61.7 \mathrm{ft}^{2}$. The test tank was supported from a cradle structure and hung from an existing rail support system in the $\mathrm{K}$-Site vacuum chamber, as shown in Fig. 2. During testing the slush hydrogen was transferred into and expelled from the test tank through a 1.5 in. diameter port in the bottom of the test tank. A stainless steel tank lid at the top of the tank contained a $1.5 \mathrm{in}$. diameter port to bring pressurant gas into the tank ullage space. Inside the test tank an $8.0 \mathrm{in}$. diameter hemispherical diffuser attached to the pressurant line dispersed the pressurant uniformly in all directions into the ullage volume. The lid also contained various feed-throughs for the test tank instrumentation. The test tank had a view port with a $3.25 \mathrm{in}$. diameter window on which a camera was mounted to allow visual observation of the testing. Four quartz lamps were mounted at various levels in the tank to provide lighting. 
During testing only one lamp was operated at a time at $\sim 30$ to $35 \mathrm{~W}$ to minimize heat addition to the system.

The test tank instrumentation is shown in the Fig. 4 schematic. Details on the instrumentation in the test tank are provided in Refs. 13 and 14. Platinum resistance temperature (PRT) sensors were used in measuring the tank wall temperatures. Chromel-constantan thermocouples and PRT sensors were used to measure tank lid temperatures. Chromelconstantan thermopiles, PRT sensors, and silicon diodes provided temperature distribution measurement of the ullage gas inside the test tank. Thermopiles were used in previous liquid hydrogen tests ${ }^{10,11}$ and the current tests because of their fast response time to the varying temperature in the ullage gas. ${ }^{16}$ A capacitance liquid level probe was used to provide continuous level measurement in the tank. Tank pressure was continuously monitored by a 0 to 100 psia strain gage type pressure transducer. The output of this transducer was fed back to the closed-loop controller used to increase the tank pressure by addition of gas through the main pressurant line during pressurization. An NRA densimeter with a $25 \mathrm{mCi}$ cesium 137 source was horizontally mounted on the transfer line $\sim 9 \mathrm{ft}$ from the tank inlet to provide density measurements during tank fill and expulsion.

\section{Testing Procedures}

Slush hydrogen tests used slush hydrogen produced in the facility production subsystem. The slush hydrogen was made using the evaporative cooling, or "freeze-thaw" process. In the freeze-thaw method the generator pressure was lowered to the triple point of hydrogen, $1.02 \mathrm{psia}$ and $24.8^{\circ} \mathrm{R}$, and solid hydrogen was formed on the surface of the liquid. Following formation of the layer of solid lydrogen, the pressure in the generator was allowed to increase and the solids sank into the liquid. One freeze and thaw was referred to as a cycle, and repeated cycling accumulated solids. This cycling process (freezing and thawing) around the triple point was repeated until the solid fraction reached a desired level. The change in pressure from the freeze through the thaw portion of the cycle could be increased through addition of gaseous helium to the generator ullage. A propeller-type mixer was used during the process to help break up the solids and to keep the slush hydrogen homogeneous. The generator typically contained I 100 gallons of normal boiling point liquid hydrogen at the start of production. After cooling the liquid to triple point temperature it would take $\sim 3$ to $4 \mathrm{hr}$ of freeze-thaw cycling to generate a batch of slush hydrogen of at least 50 percent solid fraction. The average batch size was $\sim 800$ gallons.

After production and prior to slush hydrogen transfer, the test tank and transfer line were prechilled using normal boiling point liquid hydrogen. Immediately after the tank was pre-chilled the slush hydrogen transfer process was initiated.
The generator was pressurized with gaseous helium to a desired pressure ( 35 psia in most cases) and the appropriate valves were opened to beg in the transfer. The slush hydrogen flowed through the line bypassing the test tank until the line densimeter indicated approximately the same density as the generator densimeter. At this point the bypass valve was closed and the test tank valve was opened and the test tank fill with slush hydrogen was started. For the slush hydrogen cases the test tank was filled with slush hydrogen to $\sim 5$ percent ullage. During the fill process the pressure drop through the transfer system was measured using the pressure sensor in the line near the generator outlet and the test tank pressure measurement. The flow rate during transfer was obtained by measuring the change in liquid level in the test tank and calculating the volumetric flow rate based on flow time. Further details on the transfer of slush hydrogen are provided in a previous report. ${ }^{15}$

Upon completion of the test tank fill, the pressurization and expulsion test conditions were set, including desired final tank pressure. After the test conditions were set, the test tank was vented to atmospheric pressure, and the test tank ramp pressurization was started. The tank pressure ramp rate for the tests was nominally I psi/sec. Once the desired tank pressure was reached, there was a short hold period, then the outflow valve was opened and the slush hydrogen was expelled to the generator. Expulsion time was controlled by the position of the test tank outflow valve. Pressurant gas was added to the test tank through the closed-loop control system to maintain constant tank pressure through expulsion. The expulsion continued until the test tank ullage reached $\sim 95$ percent. The production process for the next batch of slush hydrogen was then started. Details of the pressurization and expulsion process are provided in Refs. 13 and 14, respectively.

\section{Experimental Test Results}

\section{Production}

Because this series of tests represented the first operation of the slush generator system, some initial production studies were performed to attempt to optimize the production process. Optimization in this test series involved minimizing production time to produce an 800 gallon batch of at least 50 percent solid fraction slush hydrogen. During the production process, freeze/thaw cycle times, mixer speed and direction, and the change in pressure were varied.

The freeze times during the production cycle were varied from 6 to $12 \mathrm{sec}$, and the thaw times were varied from 12 to $18 \mathrm{sec}$. The times were varied in an attempt to provide a good production cycle, which includes a complete surface freeze and a thaw with mininum adhesion of solids on the wall of the generator. During the production of the batches of slush 
hydrogen, the mixer speeds were varied from as low as 25 percent to a high of 60 percent of the maximum $400 \mathrm{rpm}$ speed. The direction of the mixer, whether pushing the slush mixture up or down, also had an effect on the thaw portion of the cycle. The higher mixer speeds provided thorough nixing of the slush, which ensured a better average measurement of the density of the mixture.

The change in pressure from the freeze through the thaw portion of the cycle affected the production process. The formation of the solid layer was visibly different with different changes in pressures. The adhesion of the solids to the generator wall decreased as the changes in pressure were increased by the addition of gaseous helium to the generator ullage. As the changes in pressure were decreased, the thawing action at the surface was reduced. It was possible for the entire liquid surface to be bridged with solids if a low change in pressure $(<\sim 5$ torr) continued for a number of freeze/thaw cycles. If the pressure change was too large ( $>20$ to 25 torr), a disproportionate amount of solids appeared to melt. A change in pressure between 10 and 20 torr allowed good freezing action, with a thick, fluffy layer of solids formed, and enough thawing to release the solids from the generator walls.

About 3 to $4 \mathrm{hr}$ were required to produce an 800 gallon batch of slush hydrogen of 50 percent solid fraction or greater. A total of 40 batches of slush hydrogen were produced ( 33 000 gallons) with a maximum slush solid fraction of 65 percent, corresponding to a density of $5.19 \mathrm{lb} / \mathrm{ft}^{3}$.

\section{Transfer}

Slush hydrogen was transferred through the K-Site cryogenic flow system using a pressurized transfer technique. As discussed above, the slush generator was pressurized with helium and the slush hydrogen was transferred through approximately $125 \mathrm{ft}$ of vacuum-jacketed line into the test tank. In most cases the transfer of slush hydrogen was accomplished without difficulties. There were several cases, however, where initiation of flow was not immediately achieved. In these cases, it was speculated that the slush hydrogen had either agglomerated in the bottom of the slush generator or in the initial segments of the piping. Most of these difficulties were prevented by using a higher initial upstream pressure ( 35 psia), then reducing the pressure once flow started if a lower flow rate was required. In addition, the mixer in the generator was operated to force the movement of the fluid in a downward direction immediately prior to flow of the slush hydrogen. This fluid movement provided extra agitation to eliminate agglomeration of solids that might occur in the bottom of the generator. Therefore, although some initial difficulties were encountered in the flow of slush hydrogen, these difficulties were overcome without significant changes in the testing procedure.

Figure 5 shows the volumetric flow rate versus pressure drop for slush hydrogen and normal boiling point liquid hydrogen. The data in the figure indicates that slush hydrogen and normal boiling point hydrogen exhibit similar volumetric flow rates. Calculations performed comparing the flow characteristics of the two fluids indicate that the difference in volumetric flow rate between slush hydrogen and normal boiling point hydrogen should be small, ${ }^{15}$ and this is confirmed in experimental trends. This result indicates that the flow characteristics of slush hydrogen should be predictable using standard liquid hydrogen correlations.

The change in density between the generator and the test tank was also examined. Figure 6 shows the change in solid fraction versus flow rate as compared to the FLUSH (Flow of slush) code. FLUSH is an analytical model developed to calculate pressure drop and solid hydrogen loss in slush hydrogen flow systems. ${ }^{17}$ In the figure, an absolute solid fraction loss of 0.10 would indicate that slush hydrogen starting at. for example, 60 percent solids would have 50 percent solids by the time it reached the test tank. From the figure it appears that the slush loss in all cases was less than 15 percent, indicating that a significant amount of slush hydrogen reached the test tank during transfer, as most cases started with a solid fraction of $>50$ percent. However, the scatter on the data is quite large. It is not clear at this time whether this scatter is representative of all slush hydrogen flow systems, indicating that further work is necessary to define the solid fraction loss - including alternate techniques for measuring density - in slush hydrogen flow systems.

\section{Pressurization}

Once the transfer process was completed, the slush hydrogen in the test tank was used to conduct pressurization and pressurized expulsion tests. The pressurization phase consisted of adding hydrogen pressurant gas to the test tank to raise the pressure from $\sim 14.7 \mathrm{psia}$ to the final desired pressure. Following the pressurization there was a short hold period, then the outflow valve on the test tank was opened for the expulsion tests. Three final pressure levels were used in this testing: 25,35 and $50 \mathrm{psia}$. In addition, pressurant gas temperatures of 520 and $620^{\circ} \mathrm{R}$ were used. The pressurization rate (pressure increase/pressurization time) was nominally $1 \mathrm{psi} / \mathrm{sec}$. Twenty-five slush hydrogen pressurization and pressurized expulsion tests were conducted in this test series.

Figure 7 shows a typical set of data from the pressurization tests. In this figure the pressurant requirements (mass of gas added to achieve the final operating pressure) are plotted against ullage percent for an inlet gas temperature of $520^{\circ} \mathrm{R}$. From the figure it can be seen that pressurant requirements increase as ullage fraction and final pressure increase. Both of these trends were expected as the mass of gas addled is directly proportional to the pressure and the volume of the container. In addition, the dependence of pressurant gas added on ullage volume appeared to increase as the final pressure increased. Similar trends were seen in the cases at $620^{\circ} \mathrm{R}$ inlet gas 
temperature. ${ }^{14}$ One point on Fig. 7, corresponding to a 3.8 percent ullage and 35 psia final pressure, showed a mass of gas added much lower than similar 35 psia points. Examination of the data revealed that the initial pressure for this run was 22.8 psia, much higher than the nominal 14.7 psia initial pressure in the other cases.

\section{Pressurized Expulsion}

Following the pressurization and hold periods the outflow valve was opened to initiate expulsion. Pressurant gas was added to maintained constant tank pressure during the expulsion process. Tank pressure, mass of gas added, temperatures in the ullage and tank wall, and slush hydrogen density data were obtained during the expulsion process. Figure 8 shows a typical pressure profile for the pressurization, hold, and expulsion processes. In this figure, the pressure profile showed a fairly linear increase to the desired test pressure. The pressure was maintained during hold, then a I to 2 psi pressure drop was seen at the initiation of expulsion. The tank pressure was maintained at nearly a constant pressure throughout the remainder of the test run.

Figures 9 and 10 show the pressurant gas requirements versus expulsion time for the slush hydrogen expulsion tests with pressurant gas at 620 and $520^{\circ} \mathrm{R}$, respectively. These figures indicate the amount of pressurant gas added to maintain a constant pressure in the tank during expulsion. The data was obtained at 25,35 and 50 psia tank pressures. The expected trend would be that the pressurant requirements increase as the tank pressure and expulsion time increase. These trends are illustrated by the data at $620^{\circ} \mathrm{R}$ in Fig. 9 and to some degree by the data at $520^{\circ} \mathrm{R}$ in Fig. 10 . At $520^{\circ} \mathrm{R}$ pressurant gas temperature, the trend of increasing pressurant requirements with increasing pressure and expulsion time holds for the 35 and 50 psia cases, but three of the 25 psia expulsion data points do not follow this trend. These 25 psia points show the highest pressurant requirements of the $520^{\circ} \mathrm{R}$ expulsion tests. Examination of the test conditions showed no differences in the test procedure for these points. The data does not provide a clear explanation for the higher pressurant requirements seen with these three 25 psia expulsions. Additional data will be required to understand pressurant requirements in the 25 psia test cases.

It should be noted that, although a mixer was installed in the test tank prior to the start of testing, it was evident early in the testing that this mixer was not operational. Therefore, the expulsion tests were conducted with unmixed (nonhomogeneous) slush hydrogen. Mixing of the slush hydrogen will be required for NASP, and may provide pressurant requirement results which are higher than those presented here, because mixing may cause agitation of the slush hydrogen/ullage interface. Disturbing the ullage gas/slush hydrogen interface could expose the ullage gas to slush hydrogen at low pressure (1.02 psia) and lower temperatures ( $24.8^{\circ} \mathrm{R}$ for slush hydrogen, compared to $36^{\circ} \mathrm{R}$ for normal boiling point hydrogen). This would, in turn, cause more condensation at the interface, leading to higher pressurant requirements.

The temperatures in the ullage gas and wall, the tank pressure, and the mass of gas added were all used to obtain an energy balance for the test tank. This energy balance included an accounting of the energy entering the tank due to the pressurant gas added and the environmental heat leak. The energy entering the tank is distributed to the slush hydrogen, the tank wall, and the ullage, as described in Ref. 13. Figure II shows several cases representative of the distribution of the total energy entering the tank. In the figure reading number (RDG NO.) refers to the number assigned to each test run by the data recording system. Data is presented at both 520 and $620^{\circ} \mathrm{R}$ pressurant gas temperature for each of the three operating pressures. From the experimental data it appears that the percentage of energy added to the wall remains approximately the same regardless of test conditions; the percentage of energy transferred to the wall varied between 30 and 40 percent for the slush test cases. As the pressure increased the fraction of energy to the ullage gas increased, while the energy added to the slush hydrogen (referred to as energy to the liquid in Fig. 11) decreased. The energy added to the ullage for all cases ranged from 10 to 51 percent, while the energy to the slush hydrogen ranged from 14 to 57 percent. This energy balance data will assist in developing analytical models for expulsion. ${ }^{18}$

Finally, the slush hydrogen loss during the expulsion process was examined. The solid fraction during fill ranged from 9 to 63 percent, with the average solid fraction of all test tank fills being 43 , which corresponds to a density of $5.06 \mathrm{lb} / \mathrm{ft}^{3}$. The solid fraction at the end of the expulsions ranged from zero to a high of 32 percent. Figure 12 shows the slush hydrogen solid fraction loss versus expulsion time for tests with pressurant gas at $620^{\circ} \mathrm{R}$. The indicated solid fraction change is the difference between the solid fraction measured during the slush hydrogen fill of the test tank and the solid fraction at the end of expulsion; therefore, the solid fraction loss represents the solids lost during pressurization, hold, and expulsion. It should be noted that the final solid fraction at the end of expulsion is the solids in the fluid at 95 percent ullage. As the expulsion time increased the solid fraction loss increased, as seen from the figure. This is due to the energy increase to the slush hydrogen for longer expulsion times. In the NASP application the slush hydrogen loss is actually desirable, as the slush hydrogen melts as a result of cooling of the vehicle. This vehicle cooling is a primary function of the slush hydrogen on the NASP. Further testing, especially with well-mixed slush hydrogen, is needed to verify these results. 


\section{Concluding Remarks}

Experiments were conducted at the NASA LeRC Plum Brook K-Site Facility to provide data on the production, transfer, pressurization, and pressurized expulsion of slush hydrogen.

A total of 40 batches of slush hydrogen at $\sim 800$ gallons each were produced in the first test series at K-Site, providing a total of $\sim 33000$ gallons. During production it was found that freeze-thaw cycle time, the mixer speed, and the pressure rise during the thaw portion of the cycle all significantly affected the production process.

Transfer of the slush hydrogen from the slush generator to the test tank through the K-Site flow system presented few difficulties. Flow stagnation seen in initial transfer tests was eliminated with higher generator pressures and improved mixing in the generator. Comparison of the flow characteristics of slush hydrogen and normal boiling point liquid hydrogen indicate that slush hydrogen and liquid hydrogen have similar flow properties. Further work is required in the area of density changes during flow, however, as the data from the first test series showed a large scatter, with as solid loss ranging from 0.15 to 0 .

Pressurization results indicated that the ullage volume and the final pressure were significant in determining pressurant gas requirements during pressurization. In add ition, the initial pressure was found to have a large impact on the total amount of pressurant gas added.

Pressurized expulsion experiments showed that maintaining tank pressure during the slush hydrogen expulsion process in this test configuration was not a major concern. It is suspected that in similar testing with well-mixed slush hydrogen the maintenance of tank pressure may be more difficult, and the pressurant gas requirements may be higher than those seen in these tests. Energy balance data obtained during the expulsion tests indicate that the percentage of energy added to the ullage gas increased and the percentage of energy added to the slush hydrogen decreased as the expulsion pressure increased, while the energy added to the tank wall remained essentially the same during these tests.

The data obtained during the first test series at the K-Site Facility significantly increased the database on slush hydrogen handling, and provided a basis for a decision on the use of slush hydrogen for the National Aero-Space Plane. In addition, the technology work performed at NASA Lewis Research Center provides a foundation for the consideration of slush hydrogen as a fuel in SEI applications such as advanced launch systems, space cryogenic depots, and planetary exploration vehicles.

\section{References}

1. Hannum, N.P., "Technology Issues Associated With Fueling the National Aerospace Plane With Slush Hydrogen," NASA TM-101386, 1989.

2. DeWitt, R.L., Hardy, T.L., Whalen, M.V., Richter, G.P., and Tonsik, T.M., "Background, Current Status, and Prognosis of the Ongoing Slush Hydrogen Technology Development Program for the NASP," NASA TM-103220, 1990.

3. Kandebo, S.W., "NASP Team Narrows Its Options As First Design Cycle Nears Completion," Aviation Week \& Space Technology, vol. 134, no. 13, Apr. 1, 1990, p. 80.

4. Asker, J.R., "Nuclear Rockets Gain Support for Prope1ling Mars Mission," Aviation Week \& Space Technology, vol. 134, no. 11, Mar. 18, 1991, pp. 24-25.

5. Stafford, T.P., et al., "America at the Threshold - America "s Space Exploration Initiative," U.S. Government Printing Office, May 1991.

6. Sindt, C., "A Summary of the Characterization Study of Slush Hydrogen," Cryogenics, vol. 10, Oct., 1970, pp. 372-280.

7. Sindt, C.F., Ludtke, P.R., and Daney, D.E., "Slush Hydrogen Fluid Characterization and Instrumentation," NBS-TN-377, Feb. 1969.

8. Sindt, C.F., and Ludtke, P.R., "Slush Hydrogen Flow Characteristics and Solid Fraction Upgrading," Adyances in Cryogenic Engineering, Vol. 15, 1969, pp. 382-390.

9. Stochl, R.J., and DeWitt, R.L., "Pressurant Gas Requirements for the Pressurized Discharge of Liquid Hydrogen from Propellant Tanks," AIAA Paper 69-526, NASA TM X-52573, 1969.

10. Stochl, RJ., Masters, P.A., DeWitt, R.L., and Malloy, J.E., "Gaseous Hydrogen Requirements for the Discharge of Liquid Hydrogen from a $1.52 \mathrm{~m}$ (5 ft.) Diameter Spherical Tank," NASA TN-D 5621, 1970.

11. Whalen, M.V., Hardy, T.L., Tomsik, T.M., and DeWitt, R.L., "Preliminary Data of Slush Hydrogen Propellant Tank Studies at NASA K-Site Facility," NASP TM-1 131, 1991.

12. Whalen, M.V., Hardy, T.L., Tomsik, T.M., DeWitt, R.L., and Mahoney, N.B., "Pressurized Expulsion Studies of Slush Hydrogen Using Hydrogen Pressurant Gas," NASP TM-1143, 1991.

13. Hardy, T.L., Whalen, M.V., Tomsik, T.M., Mahoney, N.B., and DeWitt, R.L., "Pressurization Studies of Slush Hydrogen and Normal Boiling Point Hydrogen Using Hydrogen Pressurant Gas," NASP TM-1144, 1991.

14. Hardy, T.L., Whalen, M.V., Tomsik, T.M., Mahoney, N.B., and DeWitt, R.L., "Transfer of Slush Hydrogen Through the K-Site Facility Cryogenic Flow System," NASP TM-1136, 1991. 
15. Stochl, R.J., and DeWitt, R.L., "Temperature and Liquid-Level Sensor for Liquid Hydrogen Pressurization and Expulsion Studies," NASA TN D-4339, 1968.

16. Hardy, T.L., "FLUSH: A Tool for the Design of Slush Hydrogen Flow Systems," NASA TM-102467,1990.

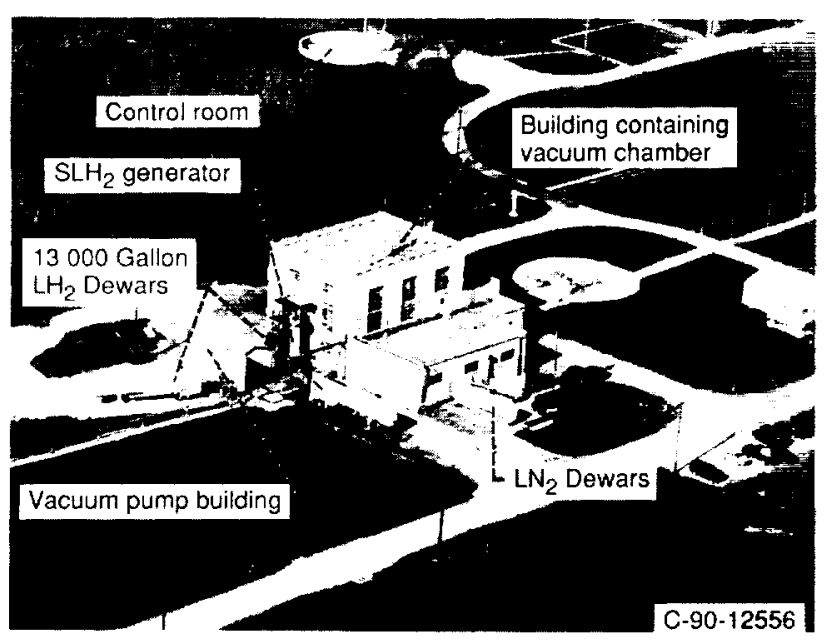

Figure 1.-NASA Plum Brook K-Site facility.

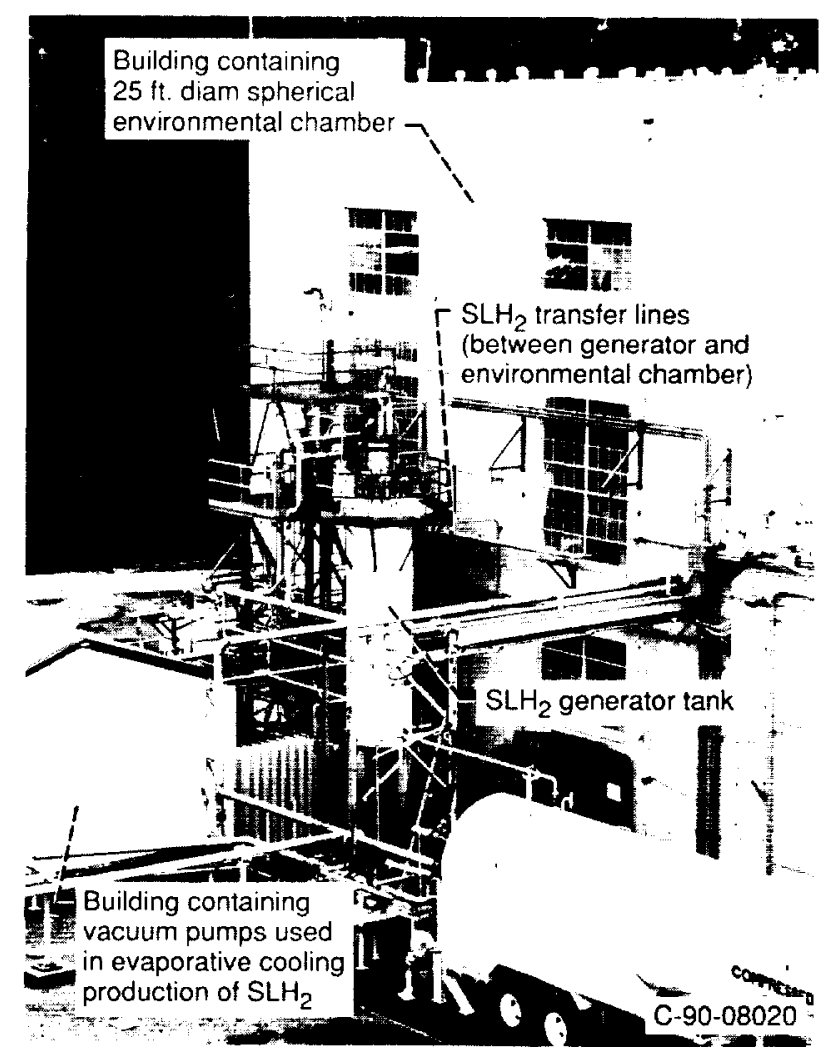

Figure 3.-K-Site $\mathrm{SLH}_{2}$ production subsystem.
17. Tomsik, T.M., and Hardy, T.L., "A Status Report on EXPL: A Computer Code for the Pressurized Expulsion of Slush Hydrogen Using Gaseous Hydrogen or Helium Pressurant Gas," NASP TM-1129, 1991.

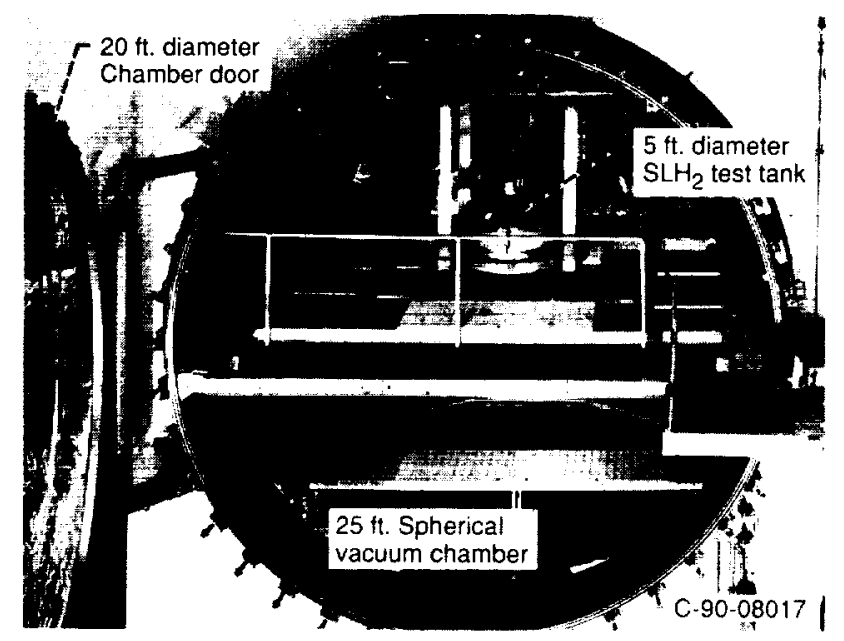

Figure 2. K- Kite 25 foot diameter spherical vacuum chamber.

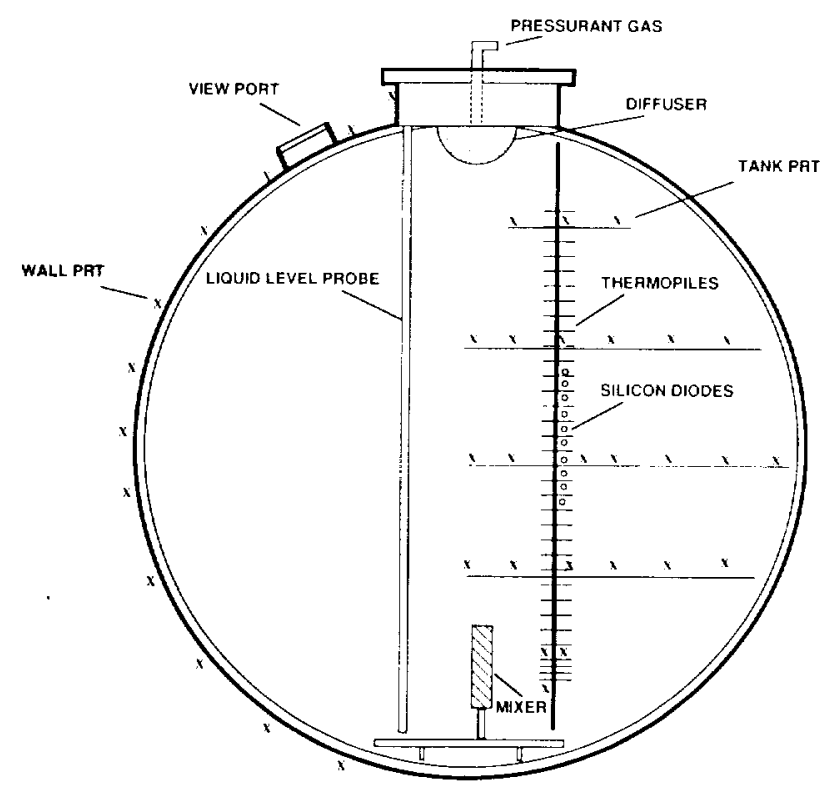

Figure 4.-K-Site slush hydrogen test tank 


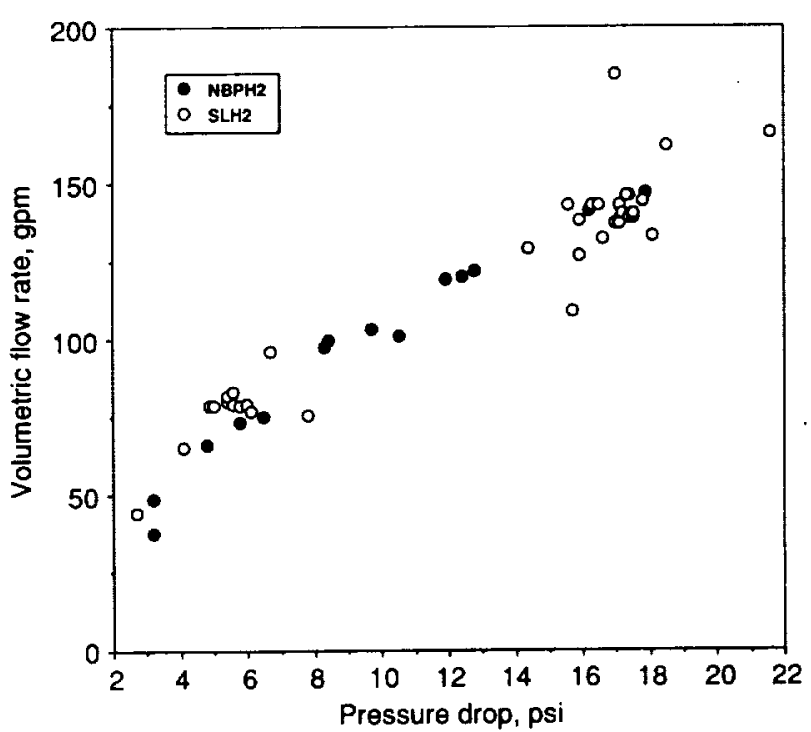

Figure 5.-Volumetric flow rate versuś pressure drop for slush hydrogen and normal boiling point hydrogen.

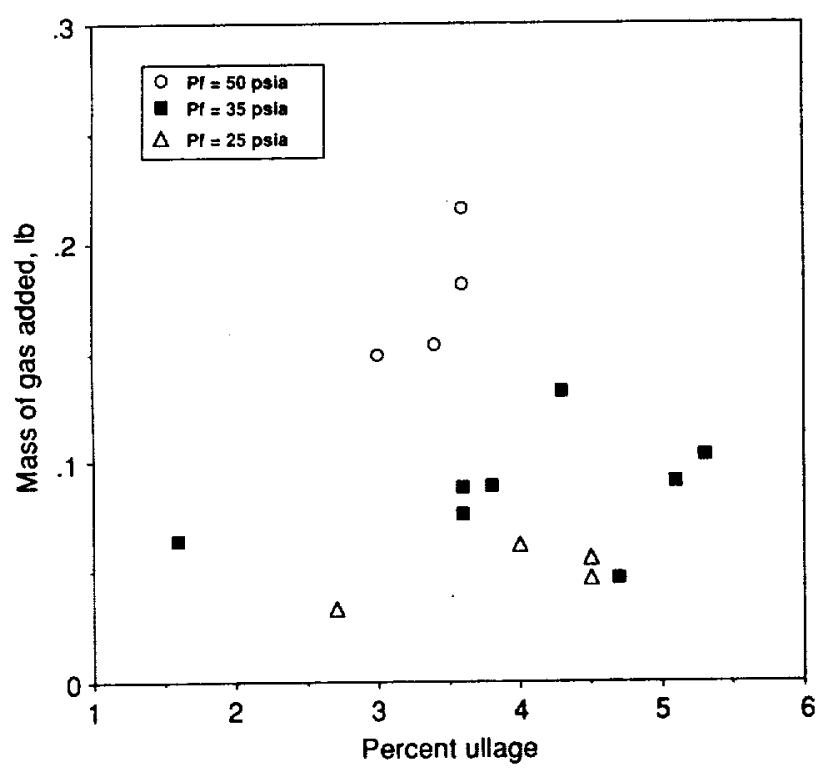

Figure 7.-Pressurant requirements versus ullage fraction: $\mathrm{SLH}_{2}$; hydrogen pressurant, $\mathrm{T}_{\text {gas }}=520 \mathrm{R}$.

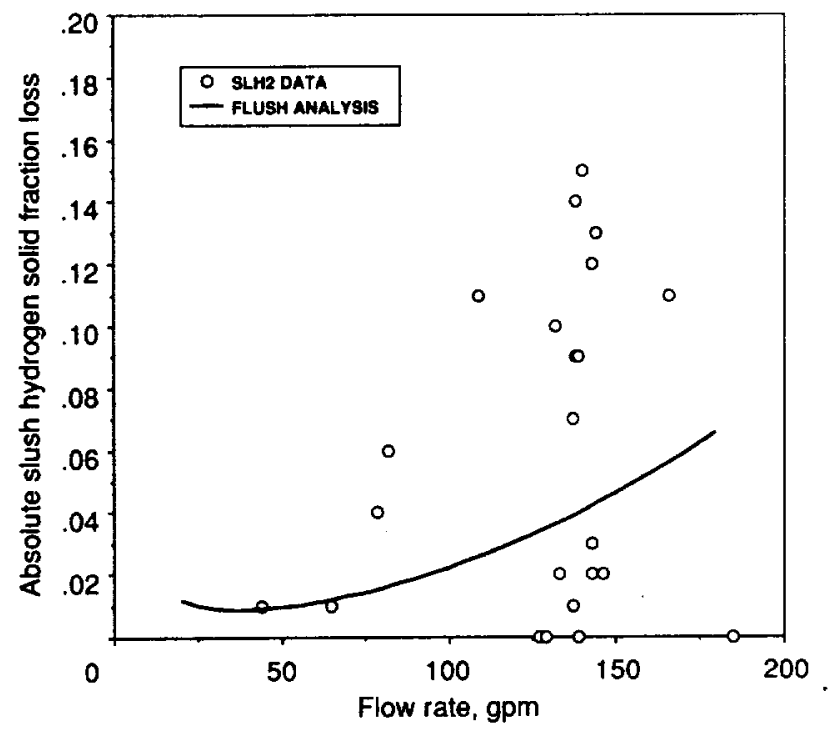

Figure 6.-Comparison of experimental solid fraction loss with FLUSH analysis.

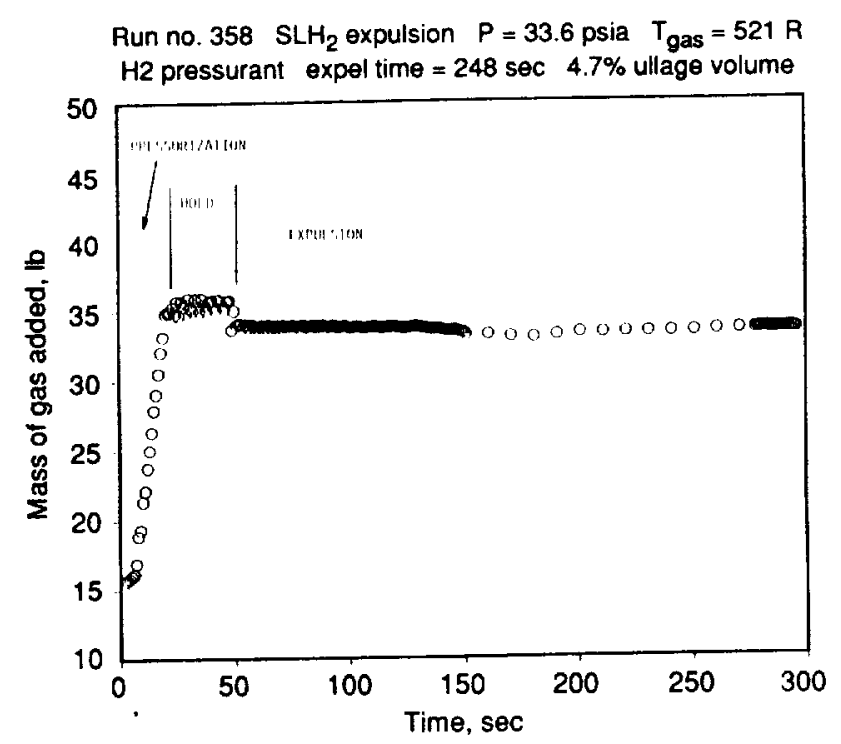

Figure 8.-Tank pressure versus time. 


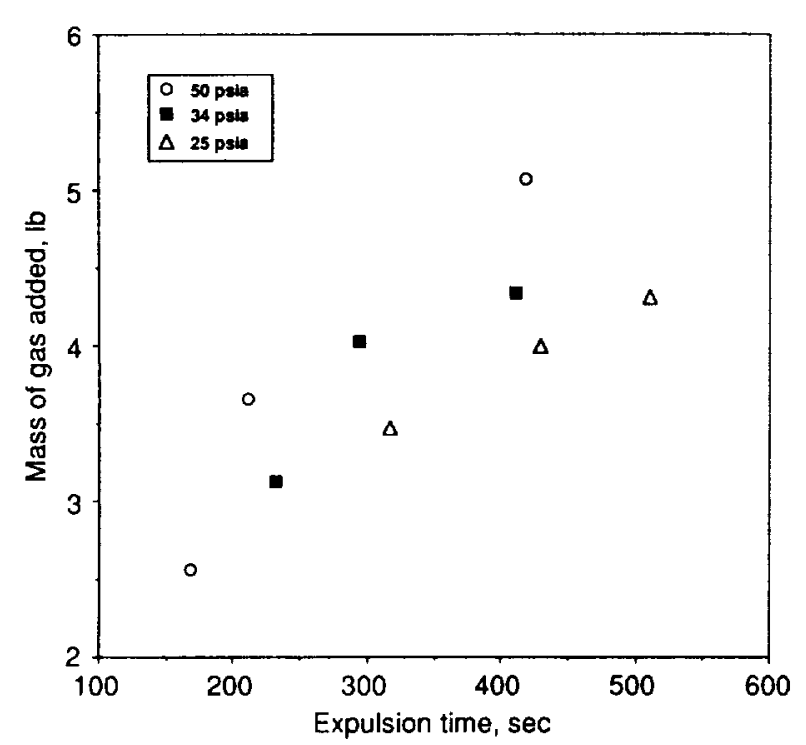

Figure 9.-Pressurant requirements during $\mathrm{SLH}_{2}$ expulsion. Hydrogen pressurant, $\mathrm{T}_{\text {gas }}=620$.

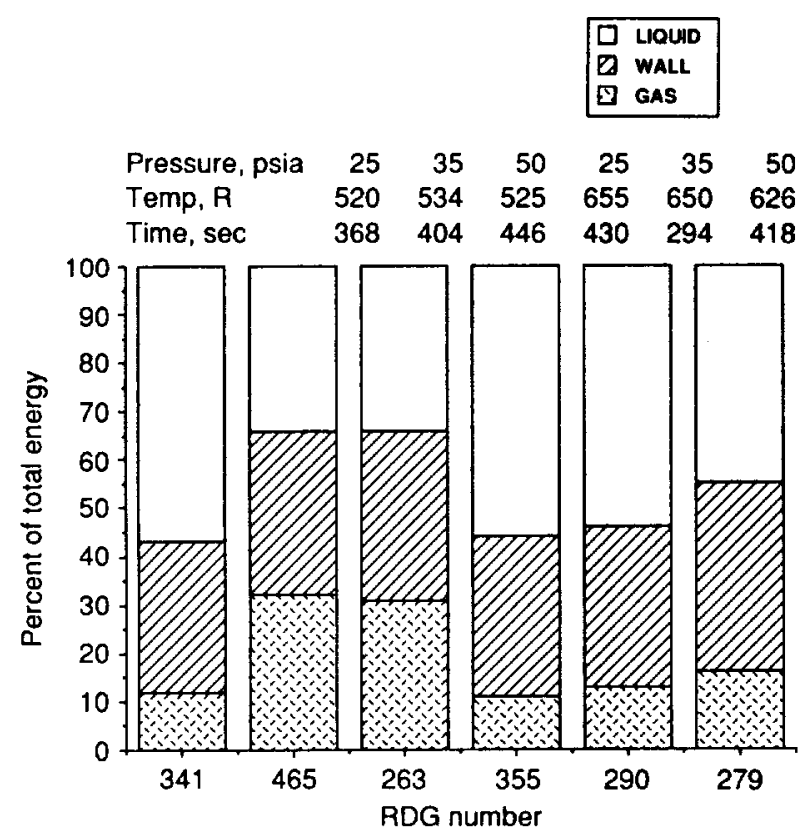

Figure 11.-Slush hydrogen energy balance.

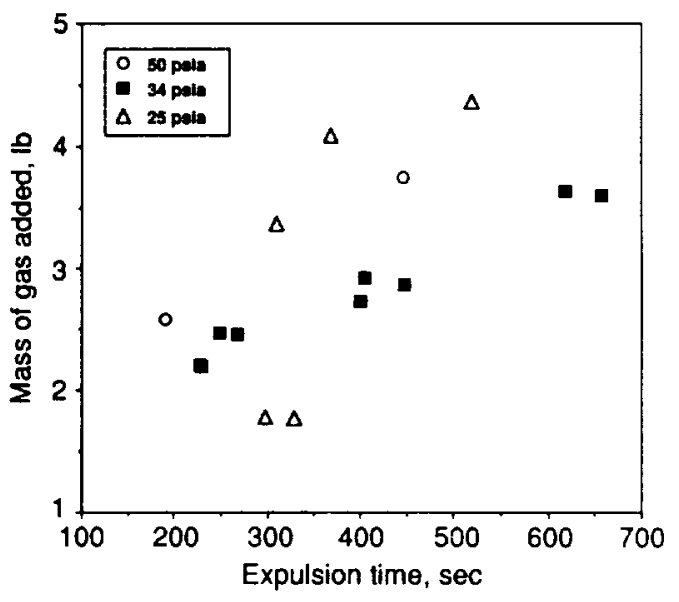

Figure 10.-Pressurant requirements during $\mathrm{SLH}_{2}$ expulsion; hydrogen pressurant, $T_{\text {gas }}=520 \mathrm{R}$.

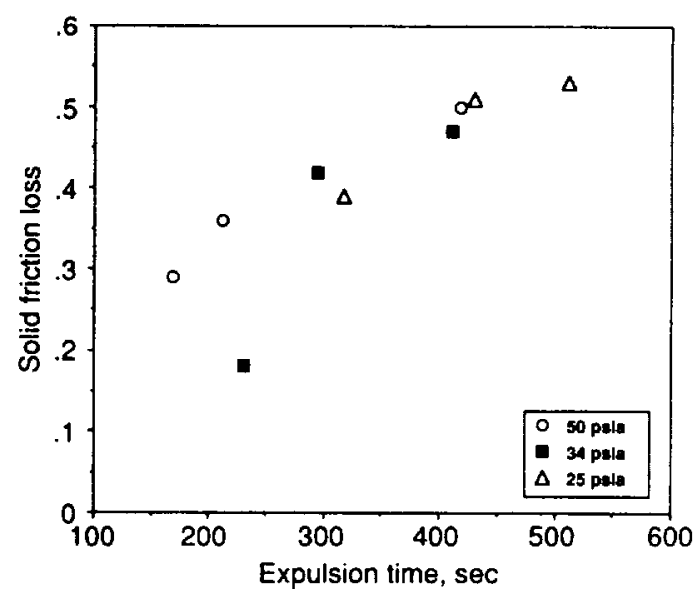

Figure 12.-Slush hydrogen solid fraction loss versus expulsion time; hydrogen pressurant gas, $T_{\text {gas }}=620 \mathrm{R}$. Solid loss based on transfer data solid fraction. 
Public reporting burden for this collection of information is estimated to average 1 hour per response, Including the time for reviewing instructions, eearching extsting dala sources, gathering and maintaining the data needed, and completing and reviewing the collection of inlormation. Send comments regarding this burden estimate or any other aspect of this coltection of Intormation, including sugestiong for reducing this burden, to Washington Headquarters Services, Directorate for intormation Operations and Reports, 1215 Jeflerson Davis Highway, Suile 1204, Arlington, VA 22202-4302, and to the Office of Management and Budget, Paperwork Reduction Project (0704-0188), Washington, DC 20503.

\begin{tabular}{|l|l|l}
\hline 1. AGENCY USE ONLY (Leave blank) & 2. REPORT DATE & $\begin{array}{c}\text { 3. REPORT TYPE AND DATES COVERED } \\
\text { Technical Memorandum }\end{array}$
\end{tabular}

\section{TITLE AND SUBTITLE}

Slush Hydrogen Propellant Production, Transfer, and Expulsion

Studies at the NASA K-Site Facility

6. AUTHOR(S)

Terry L. Hardy and Margaret V. Whalen

7. PERforming organIZation NAME(S) AND ADDRESS(ES)

National Aeronautics and Space Administration

Lewis Research Center

Cleveland, Ohio 44135 - 3191

SPONSORING/MONITORING AGENCY NAMES(S) AND ADDRESS(ES)

National Aeronautics and Space Administration

Washington, D.C. 20546-0001
WU $-763-22-21$

\section{FUNDING NUMBERS}

8. PERForming oRGanization REPOAT NUMBER

E- 6493

\section{SUPPLEMENTARY NOTES}

Prepared for the Conference on Advanced Space Exploration Initiative Technologies cosponsored by the AIAA, NASA, and OAI, Cleveland, Ohio, September 4-6, 1991. Responsible person, Terry L. Hardy, (216) $433-2411$.

12a. DISTRIBUTION/AVAILABILITY STATEMENT

12b. DISTRIBUTION CODE

Unclassified - Unlimited

Subject Category 28

\section{ABSTRACT (Maximum 200 words)}

Slush hydrogen is currently being considered as a fuel for the National AeroSpace Plane (NASP) because it offers the potential for decreased vehicle size and weight. However, no large-scale data was available on the production, transfer, and tank pressure control characteristics required to use the fuel for the NASP. Therefore, experiments were conducted at the NASA Lewis Research Center K-Site Facility to improve the slush hydrogen database. Slush hydrogen was produced using the evaporative cooling, or "freeze-thaw," technique in batches for approximately 800 gallons. This slush hydrogen was pressure-transferred to a $5 \mathrm{ft}$ diameter spherical test tank following production, and flow characteristics were measured during this transfer process. The slush hydrogen in the test tank was pressurized and expelled using a pressurized expulsion technique to obtain information on tank pressure control for the NASP. Results from the production, transfer, pressurization, and pressurized expulsion tests are described.

14. SUBJECT TERMS

Hydrogen; Hydrogen fuels; Liquid hydrogen; Cryogenic fluids; Cryogenic fluid storage; Cryogenics; National AeroSpace Plane Program; Space exploration

17. SECURITY CLASSIFICATION OF REPORT

Unclassified
18. SECURITY CLASSIFICATION OF THIS PAGE Unclassified
19. SECURITY CLASSIFICATION OF ABSTRACT Unclassified
15. NUMBER OF PAQES 10

16. PRICE CODE $\mathrm{A} 02$

20. LIMITATION OF ABSTRACT 